\title{
Far-right discourse as legitimacy? Analysing political rhetoric on the "migration issue" in Greece
}

\author{
Salomi Boukala, Panteion University of Social \& Political Sciences, Department of Social \\ Anthropology, Greece \\ salomi.boukala@panteion.gr
}

\begin{abstract}
This article advances research on the normalisation of far-right rhetoric on the "migration issue" by analysing statements from the current Greek prime minister, Kyriakos Mitsotakis, and the ruling political party New Democracy political figures. Having presented the discourse-historical approach (DHA) from critical discourse studies (CDS) as a suitable theory and method of analysis of political discourses, I use an argumentative-based DHA approach and add the argumentative schemes of Aristotelian topoi and fallacies to explore how the leadership of the conservative New Democracy government adopted far-right rhetoric on the refugee issue to justify its tough political agenda on security, law, and order. In particular, I focus on the representation of migration as a threat to national security and public health, the politics of hate, and theories of securitisation via an in-depth analysis of the current and former prime ministers' discourses, the former government spokesman's statement on the refugee issue and a popular journalist and New Democracy's MP television interview, and intend to illustrate how extreme right rhetoric could serve the conservative New Democracy's political strategies.
\end{abstract}

Keywords

New Democracy, discourse-historical approach, topos, fallacy, argumentation, Greek politics, securitisation

\section{Introduction}

The refugee issue has dominated the Greek political scene since 2015 and was highlighted as one of the main issues of the conservative New Democracy's election campaign in July 2019. In a polarised climate, New Democracy accused the radical left Syriza of cultivating a welcoming culture for migrants in Greece; and the leader of the conservative party, Kyriakos Mitsotakis, promised to reduce migration by deporting thousands of asylum seekers living on Greek islands back to Turkey. In October 2019, a few weeks after Kyriakos Mitsotakis' victory in a snap national election, the new conservative government presented its agenda for the refugee issue, which revealed its xenophobic views (Livitsanos, 2019). Deportations, the opening of detention centres, enhancement of borders security, and tougher asylum laws that reduce the safeguards for people seeking international protection synthesise the new government's policy. The new migra- tion policy challenges the humanitarian dimension that the Syriza government (2015-2019) had attempted to include in its policy during the refugee crisis in 2015, in contrast to the "closed borders" and "blame gaming" strategies that had been adopted by other European governments (Boukala \& Dimitrakopoulou, 2018, p. 183). One of the main points of the new government's policy was the closure of the Ministry of Migration and the transfer of its responsibilities to the Ministry of Citizens Protection, which is affiliated to the police and related services; a strategy accompanied by the law-and-order dogma that characterises the new conservative government. Moreover, the New Democracy government adopted a new narrative, insofar as Kyriakos Mitsotakis emphasised that Greece faces "a migration problem and not a refugee issue" (Mitsotakis, 2019), ${ }^{1}$ a view shared by Makis Voridis and

1 All the extracts which appear in this article have been translated into English by the author. 
Adonis Georgiadis, former extreme-right figures who currently serve in the government as ministers and usually refer to migrants who arrive in Greece as illegal (Boukala, 2021). In this article, I emphasise New Democracy's far-right tradition, which has resurged due to the electoral rise of the left since 2012, and present the party's move to extreme rhetoric through the prism of the conservative government's migration policy. In what follows, I first briefly review the political terrain in Greece, from the transition to democracy in 1974 to the election of the radical left Syriza in 2015, and especially the role of the extreme right and its links to the conservative party, New Democracy. In a second step, I present the discourse-historical approach (DHA) from critical discourse studies (CDS) as a suitable method to analyse, understand, and explain the intricate historical and ideological complexities of Greek political discourse. In particular, I introduce a DHA approach to the concepts of Aristotelian topoi, fallacies and argumentation strategies (Boukala, 2016, 2019) with which I show how extreme-right rhetoric has been revived and legitimised by the New Democracy party, and shaped Kyriakos Mitsotakis' government's migration policy on the basis of national security and public health. In other words, drawing on the theory of securitisation and the concept of sovereignty, this article explicates the mainstreaming of extreme-right discourse through the prism of the migration issue, which, since 2015 and the then escalation of the refugee crisis, has been a battlefield for European politics and led to the rise of right-wing extremism.

\section{New Democracy's ideological transformation in the Greek political spectrum - From Metapolitefsi to the refugee crisis}

The Greek political system that emerged after the transition to democracy (Metapolitefsi) in 1974 has been characterised by a two-party system. The parties that dominated were the Panhellenic Socialist Movement (PASOK) that developed a socialist pole in Greece and the conservative New Democracy that among others brought together ex-army officers, ex-junta officials and anti-communists (Boukala, 2021; Nikolakopoulos, 2005; Vernardakis, 2011).

The results of the two 2012 national elections led to the meltdown of traditional political power, while the radical left coalition, Syriza, thrust itself to the forefront of the political stage - an electoral rise that was sealed by the 2015 election victory of Syriza and the formation of Tsipras' coalition government. The rise of the radical left has been described as a result of the delegitimation of the political system, which developed under the impact of Greek socio-political instability and the sovereign debt crisis (Boukala \& Dimitrakopoulou, 2017; Verney, 2014). The political transformation in Greece was also marked by the entry of the Neo-Nazi party Golden Dawn into the Greek government and the legitimation of the extreme right in the Greek political spectrum, through the participation of the far-right Popular Orthodox Rally (LAOS) in the cabinet of Lucas Papademos ${ }^{2}$ (2011-2012). Another important dimension of the political climate of that era was the resurgence of historical dichotomies expressed by a polarising political rhetoric of New Democracy's political figures (Boukala, 2014). In the next paragraphs, I briefly present the ideological roots of the New Democracy party and its links to far-right extremism, which were revived as the party's current leaderships focused on a nationalist, xenophobic and anti-communist agenda as a political strategy against the electoral rise of the left (Boukala, 2021).

In particular, New Democracy's ideological base remained vague from its establishment in 1974 as the party integrated a branch of the pro-junta far-right, and during the next decades was extended from authoritarianism to neoliberalism.

2 Lucas Papademos was the former vice president of the European Central Bank, who served as prime minister of Greece in the emergency government following the collapse of PASOK government in November 2011. 
According to Vernardakis (2005, pp. 102103), the political character of the party has been shaped by three different periods: Konstantinos Karamanlis' radical liberalism (1974-1981), the far-right period of Evangelos Averoff (1981-1984) and the neoliberal period of Konstantinos Mitsotakis (1984-1993). Although ideological divergences marked New Democracy's different leaderships in the 1970s and 1980s, the party developed a traditional right ideological tag, in contrast to the other political pole of the two-party system, the socialist PASOK. New Democracy experienced a political transformation under Kostas Karamanlis' leadership (1997-2009), as he attempted to lead the party towards centrism by focusing on middle-ground politics (Vernardakis, 2011) and removing the "curse" of the far-right from the party; a political move that led to the resurgence of the far-right as an autonomous ideological pole and the creation of the LAOS. Antonis Samaras' leadership (2009-2015), accompanied by the Greek debt crisis, led to the revival of the far-right within New Democracy and in Greece in general. Political figures of the Greek far-right who were in the forefront during the period of nationalist fervour in the 1990s, due to the conflict between Greece and the then FYROM - today North Macedonia, over the name Macedonia and Greece's northern neighbour's claim to it, joined Lucas Papademos' coalition government (20112012) and thereafter the conservative New Democracy party under Antonis Samaras' leadership (Boukala, 2021). The same figures had also presumed upon the then migration issue in the 1990s, the unlimited arrival of Eastern European immigrants together with the lack of a coherent immigration policy, and communicated their nationalist and xenophobic views from the front stage politics during the refugee crisis in 2015 (Boukala, 2021).

Here, I would like to introduce two significant political figures that move their political views through the political mainstream far from the far-right's sidelines. Firstly, Makis Voridis, founder and president of the far-right Hellenic Front party-a political party that was characterised by its resemblance with Le Pen's National Front, supporter of the nouvelle droite, ${ }^{3}$ current Minister of the Interior, former Minister of Rural Development (2019-2020), Minister of Health (2014) and Minister of Transport and Networks (2012-2014) in the coalition government under the presidency of Lucas Papademos (2011-2012). Secondly, Adonis Georgiadis, current Minister of Development and Investments, vice president of New Democracy and former Minister of Health (2013-2014), who was also appointed Deputy Minister of Development in the coalition government of Lucas Papademos.

The political heritage of the Greek farright that was based on anti-communism and ideological dichotomies, established during the white terror against pro-communist and leftist civilians by the national guard militaries and paramilitaries (19451946) and the Greek civil war (1946-1949) (Panourgia, 2009), had become mainstream insofar as Samaras' New Democracy adopted an extreme rhetoric developed under the mantle of nationalism and protection of the Greek nation against the Syriza "red menace" and the refugee crisis (Boukala, 2021). In this vein, New Democracy's extreme right tradition that was slowly forgotten as the party embraced the centre, was revived in parallel with divided memories of the past.

In January 2016, the current Greek prime minister, Kyriakos Mitsotakis, was elected president of New Democracy. In contrast to Antonis Samaras' nationalist and polarised agenda, Mitsotakis' election to the party leadership was considered anti-populist, neoliberal and EU-oriented. However, Kyriakos Mitsotakis soon revived the party's far-right tradition by nominating Makis Voridis and Antonis Georgiadis as spokesmen for the party and cultivating polarisation and ideological enmity between right and left (Boukala, 2021). Security became the main issue of his po-

3 By the concept of nouvelle droite I refer to the French intellectual movement that developed in the late 1960 s, which shaped the ideological roots of the extreme right and was created in opposition to the political heritage of the left (Bar-On, 2011). 
litical agenda and a terrain of political juxtaposition that illustrated the regularity of the far-right turn of the party. Migration and the emergence of the refugee crisis (2015-2016) became the number one issue of national security and was discussed on the basis of a far-right rhetoric that reveals the normalisation of the extreme right in the Greek political spectrum, as I attempt to show in the next sections analysing political discourse.

\section{Methodology: Synthesising critical discourse analysis and argumentation}

According to Norman Fairclough (1993, p. 64) discourse could be considered a "practice not just of representing the world, but of signifying the world, constituting and constructing the world in meaning". By utilising the term discourse, Fairclough underlines the relation between language and society. In this way, he explicates that discourse contributes to the construction of social identities, social relationships and beliefs of a society's functions, given that practices are partly discursive and also discursively represented. Different approaches to critical discourse studies (CDS) underline this coexistence, and the discourse-historical approach (DHA) especially considers discourse to be "context-dependent semiotic practices, as well as socially constituted and socially constitutive, related to a micro-topic and pluri-perspective" (Reisigl \& Wodak, 2009, p. 89). Hence, the DHA can reveal the links between discursive practices, social variables, institutional frames and socio-political and historical contexts. For this reason, the DHA is a useful theory and method with which to analyse and explain the complexities, and historical and ideological dichotomies employed in Greek political discourse.

As Reisigl and Wodak (2001) further explain, the DHA employs three dimensions of analysis. These are: the specific contents or topics of specific discourses; discursive strategies; and the linguistic means that are used to disclose both topics and strat- egies (Reisigl \& Wodak, 2001). Five types of discursive strategies are involved in construing a positive Self and negative Other presentation and explicating the main linguistic and pragmatic elements, rhetorical tropes, and argumentative schemes that establish the discursive opposition between "Us" and "Them"-referential or "nomination", "predication", "argumentation", "perspectivisation", and "intensification or mitigation" (Reisigl \& Wodak, 2016, p. 33). In this chapter, I emphasise referential or nomination strategies, which highlight the representation of social actors via the usage of linguistic tropes such as metaphors. I also focus on predication strategies which shed light on the discursive characterisation of social actors. Finally, I emphasise argumentation strategies through which positive and negative attributions of social actors are justified and legitimised (Reisigl \& Wodak, 2001, 2016). According to Reisigl and Wodak $(2001,2016)$ the DHA is distinguished from other schools of critical discourse analysis (CDA) mainly due to its emphasis on argumentative schemes. Thus, here I intend to contribute to the discussion on the relation between the DHA and argumentation by synthesising the DHA and the Aristotelian thought. The concepts of Aristotelian topoi and fallacies are the main argumentative tools of the DHA and ensure an indepth analysis of the fallacious arguments usually employed by politicians in their rhetoric (Reisigl \& Wodak, 2001, 2016), and these can allow a holistic study of the fallacious reasoning and strategies of political communication employed by New Democracy's political figures. Topoi are integrated into the area of dialectic, which Aristotle calls endoxon (see also Rigotti \& Greco, 2019). Endoxon refers to a previous, commonly accepted opinion, whose validity is examined by dialectic syllogism. According to Aristotle (1992), topoi are search formulas that examine endoxon, or common knowledge, and comprise fallacious reasoning. Aristotle uses the concept of endoxon to describe an opinion that can be accepted by the majority of people because it represents traditional knowledge. As he further explains, dialectic topoi are 
the means and places for the development of dialectic syllogisms; they are the means by which a dialectician verifies endoxa and solves a dialectic problem through predicables, while topoi in Rhetoric (Aristotle, 2004) are a means of persuasion.

In Rhetoric, Aristotle (2004, B23) categorises the topoi that apply to all subjects / topics in common and can be used to explain general arguments that are not referred to specific situations. Rubinelli (2009, p. 84) has noted that the above topoi are "argument schemes, they are all devices for arriving at a certain conclusion about a case". As Boukala (2019) also explains, these topoi can be applied to every rhetorical case, while they do not all have universal applicability. Aristotle (2004, B23) provides a holistic classification of topoi that can be used by interlocutors to persuade an audience (though they might be named differently) of their argument. For this reason, topoi can be useful in a systematic analysis of various discourses. Aristotle also distinguishes between "topoi of probative / real enthymemes" and "topoi of fallacious enthymemes"; and, as he explicates, via a number of examples, topoi are usually expressed by the proposition "if one, then the other" (Boukala, 2019; Reisigl \& Wodak, 2016). Thus, topoi have a main role in the analysis of argumentation and the formation of argumentation strategies. Moreover, fallacious arguments are widely adopted in prejudiced and discriminatory discourse (Boukala, 2016; Reisigl \& Wodak, 2016; Rigotti \& Greco, 2019).

Aristotle (1994, 164a 19-21) also defines fallacies by explaining that they are "arguments that appear to be logical refutations, but in fact they are not; they are fallacies (paralogisms)". Thereafter, Aristotle provides a systematic classification of fallacies that seem to be diachronic, insofar as they can be re-used for the coherence of current political argumentation and can also contribute to the recognition of fallacies that dominate contemporary political discourse. Various scholars and disciplines have focused on fallacies as a means to serve the justification of discrimination and binary oppositions (Reisigl \& Wodak, 2001). In particular, the study of fallacies, like the study of topoi, holds an important place in argumentation theory, Pragma-dialectics and the DHA. Van Eemeren and Grootendorst (1987) developed a set of norms for the identification of fallacies and the development of a critical discussion of false reasoning. Hence, an argumentative tactic that violates any of the rules below is evaluated as fallacious. These rules can be summarised as follows:

1. Parties must not prevent each other from advancing or casting doubt on standpoints.

2. Whoever advances a standpoint is obliged to defend it if asked to do so.

3. An attack on a standpoint must relate to the standpoint that has already been advanced by the protagonist.

4. A standpoint may be defended only by advancing argumentation relating to that standpoint.

5. A person can be held to the premises he leaves implicit.

6. A standpoint must be regarded as conclusively defended if the defence takes place by means of arguments belonging to the common starting point.

7. A standpoint must be regarded as conclusively defended if the defence takes place by means of arguments in which a commonly accepted scheme of argumentation is correctly applied.

8. The argument used in a discursive text must be valid or capable of being validated by the explicitization of one or more unexpressed premises.

9. A failed defence must result in the protagonist withdrawing his standpoint and a successful defence must result in the antagonist withdrawing his doubt about the standpoint.

10. Formulations must be neither puzzlingly vague nor confusingly ambiguous and must be interpreted as accurately as possible (van Eemeren \& Grootendorst, 1987, p. 284-292).

As van Eemeren, Garssen and Meuffels (2009) further elucidate, if any of the above norms are violated, we are no longer dealing with topoi, but with fallacies. Fallacies are analysed in Pragma-dialectics "as dis- 
cussion moves which threaten the resolution of a dispute; they are violations of the rules of critical discussion" (van Eemeren \& Grootendorst, 1987, p. 297). The DHA also serves to emphasise fallacies and false reasoning. As Reisigl and Wodak (2001, 2016) note, the line between reasonable and fallacious argumentation cannot be drawn clearly in any case. Based on this observation, I would argue that the introduction of a DHA-informed systematic analysis of the Aristotelian tradition can contribute to an in-depth study of those arguments, which reveals the correlation between the farright and right-wing. Furthermore, it emphasises historical dichotomies that dominated the Greek political scene, and still do. In the next section, I examine the above hypothesis by analysing political speeches and statements of the current and former prime ministers - Kyriakos Mitsotakis and Antonis Samaras respectively, as well as the Greek government spokesman, Stelios Petsas' statements and New Democracy MP, Konstantinos Bogdanos' television interview on the migration issue by utilising the three DHA discursive strategies mentioned above and focusing on topoi and false reasoning.

\section{Analysis: The discursive construc- tion of the threat of migration}

New Democracy's national congress took place in Athens in November 2019, after the party's electoral success and the formation of Kyriakos Mitsotakis' cabinet. During the congress, the current president and prime minister of Greece, and former presidents of the party, had the opportunity to discuss New Democracy's principles and the new government's political agenda. The former president of the party and prime minister of Greece, Antonis Samaras, underlined the migration issue. As he mentioned in his speech (Samaras, 2019):

We should respect the refugees and offer them hospitality and protection. Asia Minor refugees that arrived in Greece in 1922 did not invade the country. Moreover, Greek immigrants did not illegally enter the countries in which they arrived. In Greece we have a majority of illegal migrants. We are talking about illegal invaders, mainly from countries where there is no war or other conditions that would justify providing them asylum. Our country is under an informal illegal colonisation. Illegal migration is also a threat to European countries and the European Union.

Samaras juxtaposes the Greek refugees who arrived in Greece after the Minor Asia catastrophe in 1922 and the current refugees who "invade the country". In this way, he cultivates an antithesis that is amplified through continuous references to "illegal migrants / migration" and the neologism "illegal invaders" (Stamatinis, Archakis, \& Tsakona, 2021). Based on homonymy that according to Aristotle is a dialectical tool that examines the relation between different concepts $(2004, \mathrm{~B} 23,1401 \mathrm{a})$ or $a r$ gumentum ad hominem, ${ }^{4}$ Samaras (2019) stigmatises refugees as illegal and invaders. Hence, refugees and threat become synonymous via a fallacy of homonymy ${ }^{5}$ that violates logical validity (rule 8) and a correct reference to implicit premises (rule 5). Furthermore, the former prime minister cultivates a climate of fear via a synthesis of the fallacious topos of hyperbole $^{6}$ and the topos of the consequential, ${ }^{7}$ that here could be labelled the topos of the threat of migration and paraphrased as "if migration threatens Greece and Europe, then the new Greek government should stop it". Hence, Samaras legitimises tough migration policies by presenting the refugee issue as a threat to national security.

4 "A verbal attack on the antagonist's personality and character that based on homonymy" (Reisigl \&Wodak, 2001, p. 72).

5 Two things are homonymous when they are called by the same name but have different definitions (Aristotle, 1994, 165b).

6 A fallacious topos that illustrates how the orator construct an argument via hyperboles (Aristotle, 2004, B23, 1401a).

7 A topos that shows how the argument is used in order to urge or prevent someone of doing something. As Aristotle claims (2004, B23, 1399a) if an act has both good and bad consequences, then on the basis of the good / bad consequences it can be exhorted / blamed (Boukala, 2019). 
The nationalist views of the former prime minister and the polarised rhetoric that New Democracy adopted under his leadership revealed the party's deep rightwing roots that remained obscure. Thereafter, under Samaras' governance and its contribution to the normalisation of farright discourse, New Democracy MPs of different generations and political statuses openly presented opinions remote from the party's centrist character. A characteristic example of the legitimation of extreme right-wing views within the party is Konstantinos Bogdanos' references to the refugee issue during a television interview on 23 November 2019 (To BHMAteam, 2019) when he commented that:

Refugees should stay on deserted islands, we cannot forever be tormented by certain taboos or certain sorts of post-civil war or post-dictatorship complexes. Deserted islands are the right place where refugees can be hospitalised ... Refugees cannot have the same rights as the Greek people.

Here, Bogdanos revives haunting memories of the Greek civil war and dictatorship by referring to deserted islands where leftists were exiled and tortured. He attempts to deconstruct the importance that the Greek left have applied to these islands and, in parallel, to validate the exclusion of migrants on the basis of argumentum ad baculum, a fallacy that as Reisigl and Wodak (2001, p. 71) further explain, "serves the discrimination of the antagonist by threatening the antagonist with negative sanctions". In other words, an argument that violates rules 1 and 4 and serves the far-right audience's expectations. The same argument was adopted by the leader of the extreme right party Hellenic Solution, Kyriakos Velopoulos (2019, November 5), who declared that "Greek authorities have to move migrants to deserted islands ... they are illegal". Bogdanos and Velopoulos, however, should not claim devising the above proposition, which seems to belong to Georgios Karatzaferis, the LAOS' leader who has already proposed that "illegal immigrants should be transported to Makronisos islands" in his 2012 election cam- paign (Newsroom iefimerida, 2012). Makronisos is one of the main islands used as political prisons and places of torture for many leftists. The repetition of the above statement by far-right figures can be considered relevant to their own polarised and discriminative rhetoric, however, its utilisation by a New Democracy MP illustrates the strategic adaptation of far-right political rhetoric by the party and once again the resurgence of its extreme roots.

The spread of the COVID-19 pandemic in Europe and confirmation of the first case of the virus in Greece on 26 February 2020 led to immigration restrictions, inasmuch as the government conflated the refugee issue and the pandemic. The existence of refugee camps since 2015 and the threat of the pandemic provide a chance to the government to communicate its tough migration agenda and its necessity for the security of the Greek population. According to the government spokesman, Stelios Petsas (2020a):

\begin{abstract}
The confinement of migrants in detention centres is necessary, and it is important for local societies and our country in general. Coronavirus can only be controlled if migrants stay in detention centres. It is evident that matters such as the coronavirus can be dealt with swiftly and effectively in a closed facility, and not an anarchic, open facility, which is a health time-bomb.
\end{abstract}

In the same vein, the prime minister, Kyriakos Mitsotakis, stated on 27 February 2020 (Mitsotakis, 2020):

The migration issue has a new dimension, given that people from Iran, a country hit by coronavirus, are coming to Greece. Our islands that face public health issues need to be secured. From today, therefore, our country cites Regulation 2016/399 of the European Commission on border controls under Schengen rules, and particularly paragraph 6 , on controls to prevent a threat to public health. This means upgrading controls at the Greek border to the highest level for the greatest possible control over the virus' spread ... I have already informed the European Commission of this decision, and it must see this 
as a measure to protect health throughout $\mathrm{Eu}-$ rope, given that Greece's borders with Turkey, North Macedonia and Albania are also the external borders of the EU.

The above extracts illustrate the government's political strategy to justify its strict migration policy by comparing the two issues - migration and the pandemic - and representing migrants as potential carriers of the virus and a threat to public health via the Aristotelian fallacy due to consequence ${ }^{8}$ or argument as misericordiam, ${ }^{9}$ which violates rules 8 and 4, insofar as the argument presented by the two politicians is not valid or capable of being validated by the explication of one or more unexpressed premises. Moreover, Petsas' description of the open facilities that were constructed on the basis of Syriza's migration policy as anarchic and a "health time-bomb" criticises the previous government by underlining its deleterious political decisions via the Aristotelian topos of the consequential or the topos of the threat of migration (see above), which consist of positing a dichotomy between two political poles and their different migration policies. In addition, Mitsotakis' references to the EU and Europe's borders and the stigmatisation of Iran and Iranian migrants represent the Greek government being responsible for European public health, which it secures through its restrictive migration policy. An argument that is further developed through the Aristotelian topos of analogue consequences) ${ }^{10}$ or the DHA topos of re-

8 According to Aristotle $(1994,167 \mathrm{~b})$ the fallacy due to consequence is used to show that the implication is convertible. For instance, it is considered that it was raining because the ground is wet and when it rains the ground becomes wet.

9 As Reisigl and Wodak (2001, p. 72) explain, "an argument consists of unjustifiably appealing for compassion and empathy in cases where a specific situation of serious difficulties intended to evoke compassion and to win an antagonist over to one's side is fake or pretended".

10 A topos that explains that an argument is derived from analogy in things (Aristotle, 2004, B23 1399b). sponsibility, ${ }^{11}$ which is here based on the logic "if the Greek government is responsible for the national and Europe's security and public health, then the government should stop migration and secure European borders".

Another important case study that illustrates the government's emphasis on the borders as national and European was the tension that was created in the Greek-Turkey border region of Evros when migrants, supported by the Turkish police, attempted to cross the Greek border in March 2020. As Stelios Petsas (2020b) explained in his statement regarding the decisions of the Government Council of National Security:

\begin{abstract}
Greece is experiencing extraordinary and organised pressure by mass population movements. These people are attempting to enter Greece by using violence, and thus the country is under an active, serious, extraordinary, and asymmetrical threat to its security. For this reason, the Greek government announces that the country will upgrade its security to the maximum possible level across the country's eastern border by strengthening its police and military units. Greece will also suspend all asylum applications for one month for those who enter the country illegally. Greece will also request emergency assistance from the European Union due to the current extraordinary situation.
\end{abstract}

By recontextualising the concept of asymmetrical threat that was used by the US authorities during the Cold War and was rediscovered to characterise terrorism (Stepanova, 2008), the spokesperson focuses on the danger that Greece is facing and justifies violence in an attempt to defend national security and territory. According to Stelios Petsas, state apparatuses, such as the military and the police, ensure the national safety and the

11 According to Reisigl and Wodak (2001, p. 78) the topos of responsibility "can be summarised by the conditional formula: because a state or a group of persons is responsible for the emergence of specific problems, it or they should act in order to find solutions of these problems". 
Greek government requests "emergency assistance from the European Union due to the current extraordinary situation." In this way, the Greek government cultivates a climate of fear that is also based on the topos of the threat of migration (see above). In contrast to Antonis Samaras' rhetoric, which represented migrants as invaders in a fallacious and ambiguous way, this time the threat becomes real, insofar as the Greek government underlines the migration issue and not the conflict between the two countries: Greece and Turkey. The asymmetric threat definition was also shared by far-right figures, such as Kyriakos Velopoulos and Ilias Kasidiaris, the former spokesperson of Golden Dawn and leader of the new extreme right party, Greeks for the Fatherland, as an appeal to anti-migration and nationalist emotions. Hence, in New Democracy's discourse, the refugee issue is linked to national imaginaries, sovereignty, securitisation, and migrants through fallacies, and these topoi are presented as a severe threat to national security and public health.

\section{The enemy at the gates: Talking about securitisation and sovereignty}

Greece faced a refugee crisis in 2015 that led to a polarised climate and questioned European solidarity (Boukala \& Dimitrakopoulou, 2018). The then Greek government's (Syriza-led coalition government) policy on migration manifested a desecuritisation strategy, although it failed to produce the anticipated results (Skleparis, 2018). In contrast, the current New Democracy's government has constructed its migration policy on the basis of securitisation. Drawing upon Carl Schmitt's (1932) political theory and speech acts, ${ }^{12}$

12 Following Austin's perspective, Balzacq (2005, p. 175) explains that the basic idea of speech act theory is based on the principle that certain statements do more than merely describe a given reality and, as such, cannot be judged as false or true. Instead, these utterances realise a specific action - they are performatives as opposed to constatives that the theory of securitisation was developed to explain how political elites justify their policies in the name of security in a discursive way (Balzacq, 2005). As Boukala (2019) observes, according to McDonald (2008, p. 567), securitisation can be defined as "positioning through speech acts that are usually announced by political leaders and pertains to a particular issue, such as a threat to survival, which in turn enables emergency measures, with the consent of the relevant constituency, and the suspension of 'normal politics' in dealing with the issue". According to Rampton, Charalampous and Charalampous (2014, p. 3) "securitisation refers to 'existential threats' that mean threats to the very existence of the state and lead the authorities to move from the realm of ordinary politics into the realm of exceptional by adopting strict measures against the potential danger". Hence, securitisation is based on the discursive construction of a threat, which could lead to the reinforcement of the state power while rights could be suspended via the "state of exception" (Agamben, 2005). Indeed, as Balzacq (2005, p. 179) notes, "securitisation is a rule-governed practice, the success of which does not necessarily depend on the existence of a real threat, but on the discursive ability to effectively endow a development with such a specific complexion". In this vein, security is applied as a speech act; it does not always refer to an existential threat but represents a threat and claims a specific right to use whatever means necessary to fight it (Waever, 1995). Security, then, is linked to an imagined threat that is developed through a speech act utilised by political elites and state apparatuses. According to Williams (2003, p. 514), what makes a particular speech act a part of securitisation is the reference to "an 'existential threat,' which calls for extraordinary measures beyond the routines and norms of everyday politics". The theory of securitisation and the discursive emphasis on a threat dominates New Democracy's rhetoric on migration and forms its migration policy on the basis of exclusion and national security. It

simply report states of affairs and are thus subject to truth and falsity tests. 
also contributes to the discursive opposition between 'us' and 'them', migrants, who, as Konstantinos Bogdanos claimed, "do not have the same rights as Greeks" (To BHMAteam, 2019).

The securitisation framework, especially its earliest Copenhagen model has been criticised as elliptical or narrow, because it is exclusively focused on speech acts and the discourses of dominant actors, such as political leaders, and institutions, i.e., the State (Balzacq, 2005; McDonald, 2008; Williams, 2003). I argue that the DHA and especially its argumentation strategies contribute to the study of the discursive construction of a threat and overcome limitations that are relevant to the political concepts of securitisation theory by emphasising linguistic means and their links to power relations and ideology. By presenting the topos of the threat of migration and focusing on the fallacious arguments used by New Democracy's figures, I assume that the issue of national security and how it was discursively developed by current and former prime ministers, government spokespersons and the New Democracy MP Konstantinos Bogdanos has been analysed in a holistic way via the DHA that surpasses the limitations of speech acts and the "existential threat" emphasis. Drawing upon argumentation strategies, I attempted to show the juxtapositions between far-right discourse and New Democracy's rhetoric on migration and reveal the strategic resurgence of New Democracy's extreme right roots.

According to Brown (2010, pp. 47-48), “[w]e speak of sovereignty today as if we know what we mean when we discuss its existence, achievement, violation, assertion, jurisdiction, or even waning. Yet sovereignty is an unusually amorphous, elusive, and polysemic term of political life". Hence, sovereignty and borders are interlinked, insofar as the borders demonstrate the nation-state's sovereignty (Brown, 2010). Moreover, borders add an imaginary dimension to sovereignty by creating an "imaginative geography" (Said, 1991) or a sense of belonging within a common territory (Anderson, 2006). Thus, boundaries compose not only geographical limits but also a common, national identity and a distinction between "us" and "them". As Brown (2010, p. 69) further explains, "today, there is incitement to xenophobic nationalism and a call for states to close and secure national borders from nation-states' populations anxious about the migration 'threat'”.

In this climate of insecurity and xenophobia, closing borders is a practice of state protectionism or a state of exception (Agamben, 1998, 2005) that seeks to reduce the population's insecurity by keeping the "threat" outside national borders, thus validating the nation-state's juridical rules. Wall functions as a symbolic means that signifies borders and the opposition between 'us', inside the borders, and 'them', who are outside and need to be blocked. Walls draw upon the concept of nation-state sovereignty and the demarcation of nation-state boundaries. As Brown (2010, p. 40) further explicates, "walls defining or defending political entities have shaped collective and individual identity within as they aimed to block penetration from without". Thus, New Democracy's emphasis on invasion and asymmetric warfare legitimises the nation-state's strategy of exclusion / inclusion and provides a fallacy of protection from an alien danger that threatens national security and public health.

Sovereignty, border controls, and the discursive construction of a common enemy contribute to the acceptance of state politics which, in the case of New Democracy's rhetoric on the refugee issue, could be described as a "state of exception" (Agamben, 2005) that justifies a tough migration policy via argumentative schemes presented as topoi and fallacies and the normalisation of far-right discourse.

\section{Conclusion}

"Benefits should be provided for children born by Greek parents only" (Newsroom iefimerida, 2019) announced Konstanstinos Kyranakis, a New Democracy MP and former president of the Youth of the European People's Party. A statement empha- 
sised New Democracy's turn to nationalism and it would not have been a paradox if it were stated by a member of political parties that are on the far-right of the Greek political spectrum.

By emphasising argumentative schemes such as Aristotelian topoi and fallacies through the prism of the DHA, this article offers insights into the narrative persuasion adopted by New Democracy to legitimise its strict migration policy. By equilibrating democracy and human rights, and absolutism and racism within the ambiguous limits of a "state of exception”, Kyriakos Mitsotakis' government is seeking a position on the right of New Democracy's centrism, insofar as it shares a far-right rhetoric. Securitisation and the discursive construction of migration as an existential threat dominate the discourses of the political figures under analysis and lead to a dichotomy between an external and dangerous "them" and a "we" under threat. Nation-state imaginaries and strategies of exclusion are applied via specific fallacies and topoi that are used by New Democracy figures to persuade their audience of the validity of their arguments. By utilising the DHA and emphasising argumentation strategies, I underline micro strategies of securitisation and surveillance (Bigo, 2006) that were used by the current government to justify its migration policy. I also assume that the usage of farright rhetoric due to the migration issue by the New Democracy leaderships and members is not accidental, quite to the contrary it is an aporia of the extreme right values of the party that revived during the electoral rise of the left and Syriza's coalition government in 2015. Far-right discourses and attitudes shape New Democracy's political strategy and are expressed via the topos of threat of migration and in the name of Greek people's safety.

To conclude, "the politics of fear" (Wodak, 2015) is used by political leaders to disseminate ambiguous political decisions at critical times and is linked to the mainstreaming of far-right discourses and strategies. Following Wodak's view and the multiple dimensions of the DHA, I have shed light on the resurgence of the far-right values of the conservative New Democracy by examining, in depth, its members' discourses on the migration issue and the national security that illustrate the revival of the party's extreme voices as an aporia of the party's de-demonisation of its extreme ideological roots.

\section{Conflict of interests}

The author declares no conflict of interests.

\section{References}

Agamben, G. (1998). Homo sacer: Sovereign, power and bare life. Stanford, CA: Stanford University Press.

Agamben, G. (2005). State of exception. Chicago, IL: CUP.

Amossy, R. (2002). How to do things with doxa: Toward an analysis of argumentation in discourse. Poetics Today, 23(3), 465-487. https://doi.org/10.1215/03335372-23-3465

Anderson, B. (2006). Imagined communities. London, UK: Verso.

Aristotle. (1992). Topics. Athens, Greece: Kaktos.

Aristotle. (1994). Sophistical refutations. Athens, Greece: Kaktos.

Aristotle. (2004). Rhetoric. Thessaloniki, Greece: Zitros.

Balzacq, T. (2005). The three faces of securitization: Political agency, audiences and context. European Journal of International Relations, 11(2), 171-201. https://doi. org/10.1177/1354066105052960

Bar-On, T. (2011). Transnationalism and the French Nouvelle Droite. Patterns of Prejudice, 45(3), 199-223. https://doi.org/10.108 0/0031322X.2011.585013

Bigo, D. (2006). Globalised (in)security: The field and the ban-opticon. In N. Sakai \& J. Solomon (Eds.), Translation, biopolitics, colonial difference (pp. 5-49). Hong Kong, China: Hong Kong University Press.

Brown, W. (2010). Walled states, warning sovereignty. New York, NY: Zone Books.

Boukala, S. (2014). Waiting for democracy: Political crisis and the discursive (re) invention of the "national enemy" in times of "Grecovery". Discourse \& 
Society, 25(4), 483-499. https://doi. org/10.1177/0957926514536961

Boukala, S. (2016). Rethinking topos in the discourse historical approach: Endoxon seeking and argumentation in Greek media discourses on "Islamist terrorism". Discourse Studies, 18(3), 249-268. https:// doi.org/10.1177/1461445616634550

Boukala, S. (2019). European identity and the representation of Islam in the mainstream press: Argumentation and media discourse. London, UK: Palgrave.

Boukala, S. (2021). "We need to talk about the hegemony of the left": The normalisation of extreme right discourse in Greece. Journal of Language and Politics, 20(3), 361-382. https://doi.org/10.1075/jlp.19053.bou

Boukala, S., \& Dimitrakopoulou, D. (2017). The politics of fear vs. the politics of hope: Analysing the 2015 Greek election and referendum campaigns. Critical Discourse Studies, 14(1), 39-55. https://doi.org/10.10 80/17405904.2016.1182933

Boukala, S., \& Dimitrakopoulou, D. (2018). Absurdity and the "blame game" within the Schengen area: Analyzing Greek (social) media discourses on the refugee crisis. Journal of Immigrant \& Refugee Studies, 16(1-2), 179-197. https://doi.org/10.1080/ 15562948.2017.1303560

Fairclough, N. (1993). Discourse and social change. London, UK: Polity.

Livitsanos, G. (2019, October 17). Ti tha provlepei to neo metanasteutiko nomoshedio [What the new immigration bill will provide]. Retrieved from https:// vouliwatch.gr/news/article/ti-tha-provlepei-to-neo-metanasteytiko-nomoshedio

McDonald, M. (2008). Securitization and the construction of security. European Journal of International Relations, 14(4), 563-587. https://doi. org/10.1177/1354066108097553

Mitsotakis, K. (2019, October 4). Diloseis [Statement]. Retrieved from https:// www.kathimerini.gr/politics/1045459/ kyr-mitsotakis-to-provlima-poy-antimetopizoyme-einai-metanasteytiko-kai-ochi-prosfygiko /

Mitsotakis, K. (2020, February 27). Eisagogiki topothetisi Kyriakou Mitsotaki kata tin enarxi tou upourgikou sumvouliou [Kyriakos Mitsotakis' introductory statement at the cabinet]. Retrieved from https://www. youtube.com/watch?v=xOIXUBJrgOk

Newsroom iefimerida. (2012, April 9). Karatzaferis: Na metaferthoun oi metanastes stis makronisous [Karatzaferis: Migrants should migrate to long islands]. Retrieved from https://www.

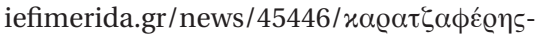
$v \alpha-\mu \varepsilon \tau \alpha \phi \varepsilon \varrho \theta o u ́ v-o t-\mu \varepsilon \tau \alpha v \alpha ́ \sigma \tau \varepsilon \zeta-\sigma \tau \iota \zeta-$

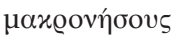

Newsroom iefimerida. (2019, June 25). Aparadektes diloseis Kyranaki (ND) [Unacceptable statement by Kyranakis (ND)]. Retrieved from https://www.iefimerida. gr/politiki/salos-kyranaki-nd-epidomata-mono-sta-ellinopoyla

Nikolakopoulos, I. (2005). Elections and voters, 1974-2004: Old cleavages and new issues. West European Politics, 28(2), 260-278. https://doi. org/10.1080/01402380500058886

Panourgia, N. (2009). Dangerous citizens. The Greek left and the terror of the State. New York, NY: Fordham University Press.

Petsas, S. (2020a, February 25). Den uparxei alli odos peran tou kuvernitikou sxediou gia kleistes domes [There is no other way except the government's plan for closed asylum camps]. Retrieved from https:// www.youtube.com/watch?v=-H8nPFyXtiE

Petsas, S. (2020b, March 1). Dilosi Steliou Petsa gia tis apofaseis tou sumvouliou ethnikis asfaleias [Stelios Petsas' statement regarding the decisions of the national security council]. Retrieved from https://www. youtube.com/watch?v=zbi3_pmeJ34

Rampton, B., Charalampous, P., \& Charalampous, C. (2014). De-securitising Turkish: Teaching the language of a former enemy and intercultural language education. Working Papers in Urban Languages and Literacies. Paper 137.

Reisigl, M., \&Wodak, R. (2001). Discourse and discrimination. London, UK: Routledge.

Reisigl, M., \& Wodak, R. (2009). The discourse-historical approach (DHA). In R. Wodak \& M. Meyer (Eds.), Methods of critical discourse analysis (3rd ed., pp. 23-61). London, UK: Sage.

Reisigl, M., \& Wodak, R. (2016). The discoursehistorical approach (DHA). In R. Wodak \& M. Meyer (Eds.), Methods of critical 
discourse analysis (3rd ed., pp. 23-61). London, UK: Sage.

Rigotti, E., \& Greco, S. (2019). Inference in argumentation: A topics-based approach to argument schemes. Cham, Switzerland: Springer.

Rubinelli, S. (2009). Ars topica: The classical technique of constructing arguments from Aristotle to Cicero. Cham, Switzerland: Springer.

Said, E. (1991). Imaginative geography and its representations. In E. Said, Orientalism (pp. 49-72). Harmondsworth, UK: Penguin.

Samaras, A. (2019, December 1). Omilia Antoni Samara sto 13 sunedrio tis Neas Dimokratias [Antonis Samaras' speech on the $13^{\text {th }}$ ND conference]. Retrieved from https://www.youtube.com/ watch?v=I39oilkYFWY

Schmitt, C. (1932). The concepts of the political. Chicago, IL: CUP.

Skleparis, D. (2018). "A Europe without walls, without fences, without borders": A desecuritisation of migration doomed to fail. Political Studies, 66(4), 985-1001. https:// doi.org/10.1177/0032321717729631

Stamatinis, N., Archakis, A., \& Tsakona, V. (2021). From the illegal migrant-criminal to the illegal migrant-invader: Critical analysis of the semantic change of the

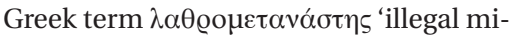
grant'. Studies in Communication Sciences (SComS), 21(2), 343-360. https://doi. org/10.24434/j.scoms.2021.02.015

Stepanova, E. (2008). Terrorism in asymmetrical conflict: Ideological and structural aspects. SIPRI Research Report No. 23. Oxford, UK: Oxford University Press.

To BHMAteam. (2019, November 23). Bogdanos: Na pane oi prosfiges sta xeronisia [Bogdanos: Migrants should go to deserted islands]. Retrieved from https://www. tovima.gr/2019/11/23/politics/mpogdanos-na-pane-prosfyges-sta-kseronisia/

van Eemeren, F., Garssen, B., \& Meuffels, B. (2009). Fallacies and judgments of reasonableness: Empirical research concerning the pragma-dialectical discussion rules. Cham, Switzerland: Springer.

van Eemeren, F., \& Grootendorst, R. (1987). Fallacies in pragma-dialectical perspective. Argumentation, 1(3), 283-301. https://doi. org/10.1007/BF00136779

Velopoulos, K. (2019, November 5). Na metaferthoun oi metanastes se akatoikita nhsia [Migrants should be transferred to deserted islands]. Retrieved from https://www. news247.gr/politiki/akraies-lyseis-apo-elliniki-lysi-metafora-metanaston-akatoikita-nisia.7527493.html

Vernardakis, C. (2005). Politika kommata kai mesaios horos: oi ideologikes, politikes kai politismikes suntetagmenes ton simerinon politikon dunameon [Political parties and the "middle space": The ideological, political and cultural orientations of the current political forces]. In C. Vernardakis (Ed.), Public opinion in Greece 2004 (pp. 57-85). Athens, Greece: Savvalas.

Vernardakis, C. (2011, April 19-21). The rise and fall of the Greek conservative party: Ideological realignments and egocentric economic voting at the dawn of the financial crisis. Paper prepared for presentation at the 61st Political Studies Association Annual Conference. London, UK.

Verney, S. (2014). "Broken and can't be fixed": The impact of the economic crisis on the Greek party system. The International Spectator. Italian Journal of International Affairs, 49(1), 18-35. https://doi.org/10.10 80/03932729.2014.877222

Waever, O. (1995). Securitization and desecuritization. In R. D. Lipschutz (Ed.), On security (pp. 46-86). New York, NY: Columbia University Press.

Williams, M. C. (2003). Words, images, enemies: Securitization and international politics. International Studies Quarterly, 47(4), 511-531.

Wodak, R. (2015). The politics of fear: What right-wing populist discourses mean. London, UK: Sage. 